\title{
Effect of the inhibiting action of additives on the macro- and microdistribution of copper during electrodeposition from sulfuric acid electrolytes
}

\author{
A.A. Kosarev, A.A. Kalinkina* and T.A. Vagramyan \\ Russian University of Chemical Technology named after D.I. Mendeleev, Miusskaya sq., 9, \\ 125047 Moscow, Russian Federation \\ *E-mail: aakalinkina@mail.ru
}

\begin{abstract}
The paper studies the effect of electrodeposition conditions on the uniformity of copper distribution and the morphology of copper coatings both on the surface and in small-diameter through holes. In order to improve the coating uniformity, a complex additive based on polyalkylene glycols, nitrogen-containing heterocyclic compounds and organic sulfurcontaining compounds was used. The results were compared with those obtained for coatings deposited from an electrolyte containing only copper sulfate and sulfuric acid but no additives. Based on a significant increase in cathodic polarization in the presence of the complex additive, an inhibitory effect on the copper electrodeposition was assumed. The electrodeposition of copper onto samples with through holes was carried out under direct current and in reverse mode. The introduction of the complex additive into the electrolyte nearly does not change the roughness parameters $R_{\mathrm{a}}$ and $R_{\mathrm{z}}$, however, it significantly affects the morphology of copper coatings obtained under direct current. It was found from the micrographs of cross-sections that the presence of the complex additive in the electrolyte without current reversal results in the formation of a flat wavy microrelief of the copper coating surface. The micrographs of the outer surface of the samples confirmed the three-dimensional shape of the microwaves whose height reaches $\sim 30-40 \%$ of the average thickness of the copper deposit. Under current reversal conditions without the complex additive, the microrelief has nearly no waviness, however, a dendritic surface with significant crystal roughness is formed. Coatings that are uniform in thickness and structure are formed on the surface of the samples and in the holes only provided that current reversal, the complex additive, and stirring of the electrolyte are used simultaneously.
\end{abstract}

Keywords: inhibiting additives, roughness, metallization of through holes, leveling, copper microdistribution.

Received: July 10, 2020. Published: August 6, 2020

doi: $\underline{10.17675 / 2305-6894-2020-9-3-11}$

\section{Introduction}

The electrodeposition of copper from sulfuric acid electrolytes has been studied in a number of works $[1,2]$, including the formation of conductive copper layers on the surface and in through-holes of printed circuit boards [3-6]. However, many regularities of the effect of 
various factors on the uniformity of copper coatings under both macro- and microdistribution conditions have not yet been studied. It has been shown that the majority of practically used additives in sulfuric acid electrolytes for copper plating exhibit inhibitory effects and have complex compositions. A series of studies revealed the beneficial effects of some additives on the morphology and grain fineness of copper deposits [7-9], improved micro- and macrodistribution of copper [4-6], and uniformity of the copper layer at the hole mouth without the so-called "dog bone" effect $[3,10]$. Various methods are used in the electrodeposition of copper on complex-shaped surfaces in order to improve the distribution uniformity and morphology of coatings. A beneficial effect of high-frequency reverse current on the uniformity of copper distribution on flat samples in a Haring-Bloom cell, especially in the presence of special additives, was noted [11]. Smooth shiny coatings are obtained in these cases. In the case of galvanic copper plating of through-holes in printed circuit boards, the combined effect of the ohmic potential drop in a solution inside the hole and the diffusion restrictions contribute to the degradation of the uniformity of the copper layer distribution [12]. To ensure the flow of electrolyte in the through-holes, a reciprocating horizontal movement of the cathode rod with a vertically suspended sample is traditionally used [12,13]. It is noted [14] that current reversal during the electrodeposition has a significant effect on the adsorption of the organic compounds contained in complex additives.

The performance of devices in ultrahigh frequency technology is considerably affected by the profile of the conductive surface. At high electric signal frequencies, the so-called "skin effect" significantly decreases the conductive layer depth $[15,16]$. The thickness of this layer is about $2.3 \mu \mathrm{m}$ at a frequency of $1 \mathrm{GHz}$ and $0.66 \mu \mathrm{m}$ at $10 \mathrm{GHz}$ [16]. With an increase in the height of irregularities above these values, the signal path length increases, resulting in its weakening or loss, as well as in growing of delays. Thus, the surface morphology of conductive copper layers and the uniformity of thickness distribution in the coating inside the holes effect significantly the performance of modern electronic devices.

The purpose of this work was to study the effect of electrodeposition conditions on the copper distribution and surface morphology in the presence of inhibiting additives, both on the surface and in holes of various diameters.

\section{Experimental procedures}

The electrolytes were prepared from copper sulfate, ferrous sulfate, sodium chloride ("pure" grade) and sulfuric acid ("chemically pure" grade). To improve the uniformity of coatings, a complex leveling additive based on polyalkylene glycols and heterocyclic nitrogencontaining compounds with 5-6 carbon atoms in the ring was used. The formulation also comprised organic sulfur-containing compounds (thiols, disulfides, sulfonic acids) as brighteners. The results were compared to those obtained for coatings deposited from the electrolyte without additives. The electrolyte compositions are presented in Table 1.

The solution was stirred by rocking the cathode bar with a vertically suspended sample in horizontal direction at a frequency of $30 \mathrm{~min}^{-1}$ and an amplitude of $2.5 \mathrm{~cm}$. The cathodes 
were degreased with Viennese lime and activated in $10 \%$ sulfuric acid solution. The anodes were made of M1 grade copper. They were etched in 30\% nitric acid for 10 seconds and activated in $10 \%$ sulfuric acid solution.

Table 1. Compositions of electrolytes.

\begin{tabular}{ccc}
\hline & \multicolumn{2}{c}{ Concentrations of components } \\
\cline { 2 - 3 } Electrolyte components & $\mathbf{1}$ & $\mathbf{2}$ \\
\hline $\mathrm{CuSO}_{4} \cdot 5 \mathrm{H}_{2} \mathrm{O}, \mathrm{g} / \mathrm{l}$ & 60 & 60 \\
$\mathrm{H}_{2} \mathrm{SO}_{4}, \mathrm{~g} / \mathrm{l}$ & 230 & 230 \\
$\mathrm{NaCl}_{\mathrm{mg} / \mathrm{l}}$ & - & 120 \\
$\mathrm{FeSO}_{4} \cdot 7 \mathrm{H}_{2} \mathrm{O}, \mathrm{g} / \mathrm{l}$ & - & 0.5 \\
Formulation of additives, $\mathrm{mg} / \mathrm{l}$ & - & 22 \\
\hline
\end{tabular}

The electrodeposition of copper onto samples of printed circuit boards with through holes was carried out at a constant current of $1 \mathrm{~A} / \mathrm{dm}^{2}$ and in a reverse mode at a frequency of $\sim 50 \mathrm{~Hz}$ (Table 2). In the case of current reversal, the ratio of the forward and reverse pulse times $t_{\mathrm{c}}: t_{\mathrm{a}}$ was $20 \mathrm{~ms}: 1 \mathrm{~ms}$. The amplitudes were $i_{\mathrm{c}}=1$ and $i_{\mathrm{a}}=3 \mathrm{~A} / \mathrm{dm}^{2}$, respectively. Copper electrodeposition was carried out using an IPC-Pro MF potentiostat (NPF Volta, Russia). The character and parameters of the current pulses were monitored using an S1$112 \mathrm{M}$ oscilloscope (CJSC ProfKIP, RF). The solution temperature during the electrolysis was $20 \pm 1^{\circ} \mathrm{C}$.

To estimate the effect of solution composition on copper distribution, cathodic polarization curves were recorded using an IPC-Pro MF potentiostat in potentiodynamic mode at a potential sweep rate of $2 \mathrm{mV} / \mathrm{s}$. A wire of M1 grade copper immersed into the same solution was used as the reference electrode.

Table 2. Conditions for electrodeposition of samples.

\begin{tabular}{cccc}
\hline Sample No. & Electrodeposition mode & Rocking & Additives \\
\hline 1 & Direct current & - & - \\
2 & Reverse current & - & - \\
3 & Direct current & - & + \\
4 & Reverse current & - & + \\
5 & Direct current & + & - \\
6 & Reverse current & + & - \\
7 & Direct current & + & + \\
8 & Reverse current & + & + \\
\hline
\end{tabular}


The uniformity of copper distribution was studied in through-holes drilled in foil-clad dielectric specimens. The diameters of holes in all the experiments were 0.2 and $0.4 \mathrm{~mm}$. The sample thickness was $1.56 \mathrm{~mm}$. The relative thickness of the copper deposit at the middle of the hole depth $d_{1 / 2}$ was estimated as percentage of the average external coating thickness, at a distance from the mouth equal to the hole radius. The thickness of the electrodeposited copper layer was determined from the micrographs of sections obtained with a LEXTOLS4100 confocal laser microscope (Olympus Europa Holding GmbH, Germany) with MPLAPONLEXT50 and MPLAPONLEXT100 lenses. The average irregularity height $R_{\mathrm{a}}$ and the maximum irregularity height $R_{\mathrm{Z}}$ of the outer surface were determined at 430x magnification (MPLAPONLEXT20 lens) on a baseline $4 \mathrm{~mm}$ long using the ROUGHESS software module in accordance with GOST R ISO 4287-2014. In addition, the roughness of the coating on the outer surface and inside the holes was estimated as the maximum irregularity height $R_{\mathrm{z}}^{*}$ at a baseline $130 \mu \mathrm{m}$ long (within the field of the MPLAPONLEXT100 lens).

\section{Results and Discussion}

According to the data of polarization measurements, the cathodic polarization increases significantly up to $\sim 150 \mathrm{mV}$ in the presence of the additive formulation (Figure 1), which may be due to the inhibiting effect on the electrodeposition of copper coatings [2, 9, 17-19].

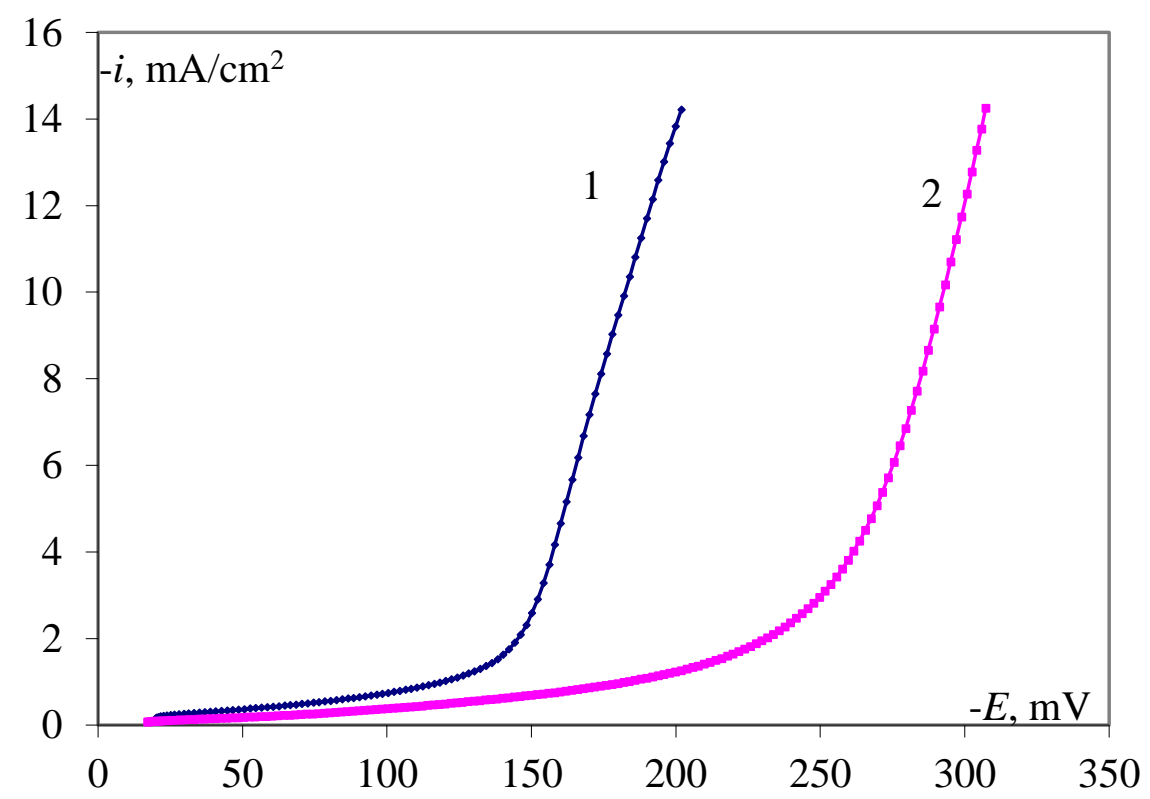

Figure 1. Cathodic potentiodynamic curves recorded at a rate of $2 \mathrm{mV} / \mathrm{s}: 1$ - in electrolyte 1; 2 - in electrolyte 2 with the additive.

According to the roughness measurement data, the $R_{\mathrm{a}}$ and $R_{\mathrm{z}}$ of the outer surfaces of copper coatings obtained at direct current in the presence of the additives and without them are approximately the same, namely, $\sim 1 \mu \mathrm{m}$ and $\sim 15 \mu \mathrm{m}$, respectively. However, as 
expected, the morphology of copper deposits obtained under direct current conditions from a solution containing only copper sulfate and sulfuric acid and in the presence of the additive differs significantly. The differences in morphology are clearly visible on $1 \mathrm{~mm}$ long fragments of the profile diagrams: while the maximum irregularity height in this area is nearly the same, i.e., 6-7 $\mu \mathrm{m}$, the irregularity step increases significantly (Figure 2a, b). In the absence of additives, the crystalline micro relief of the outer surface of a sample is irregular and is formed by a set of micro irregularities no more than $15-20 \mu \mathrm{m}$ wide (Figure 2a). According to [20], the roughness of $\mathrm{ca} \cdot 10^{-4} \mathrm{~cm}$ corresponds to the so-called crystalline roughness that is formed due to different growth rates of faces with different indices on the polycrystalline surface of a growing deposit. In the presence of additives, the coatings are noticeably smoother, a shallow micro relief is formed, and the width of irregularities increases noticeably (Figure 2b).

One can estimate in more detail how micro irregularities change with changes in the solution composition from the micrographs of cross-sections of coatings obtained at higher optical resolution than the profile diagrams. Based on a micrograph with $1000 \times$ magnification, a 3D image of the copper coating micro relief was obtained. It confirms the three-dimensional nature of the micro relief waviness in the presence of the complex additive (Figure 2c). The micrographs of the cross-sections of copper coatings on samples with holes were obtained at magnifications of $1000 \times$ and $2000 \times$. The height of irregularities of the outer surface and inside the holes $R_{\mathrm{z}}^{*}$ in the presence of additives and without them is $\sim 15 \mu \mathrm{m}$, both under natural convection conditions and with rocking of the cathode rod (Table 3 , samples 1, 5, 3, 7). However, upon copper electrodeposition from an electrolyte containing the additives, characteristic wave-like irregularities with a width of $\sim 80$ to $\sim 200 \mu \mathrm{m}$ and a height of $\sim 5$ to $\sim 15 \mu \mathrm{m}$ are formed on the external side of the board (Figure 2c, Figure 3). The micrographs of the coatings obtained without the complex additive do not show this kind of micro waviness. The width of the wavelike irregularities observed in the micrographs agrees by the order of magnitude with the roughness dimensions of $\sim 200 \mu \mathrm{m}$ in the profile diagram of the copper coating electrodeposited from the sulfuric acid electrolyte onto an electrolytically polished untextured copper cathode with an average grain size of $35 \mu \mathrm{m}$ [18]. According to [18], the appearance of such irregularities was caused by diffusion flows near the electrode surface. Taking into consideration that the recommended thickness of electroplated copper coatings on printed circuit boards is $\sim 30 \mu \mathrm{m}$ [21], a thickness difference of up to $15 \mu \mathrm{m}$ can adversely affect the mechanical and electrical properties of the coatings and hence impair the reliability of electronic devices. Various methods exist for the qualitative estimation of the distribution of electroplated copper coatings in through-holes of printed circuit boards $[5,6,9,10,17]$. Typically, all of these methods involve calculating the ratio of the average copper layer thickness at the hole half-depth to the average coating thickness on the outside of the sample. The presence of gentle micro relief waves significantly complicates the determination of the external thickness of a copper coating whose value is required for estimating the uniformity of copper layer distribution in the holes. 

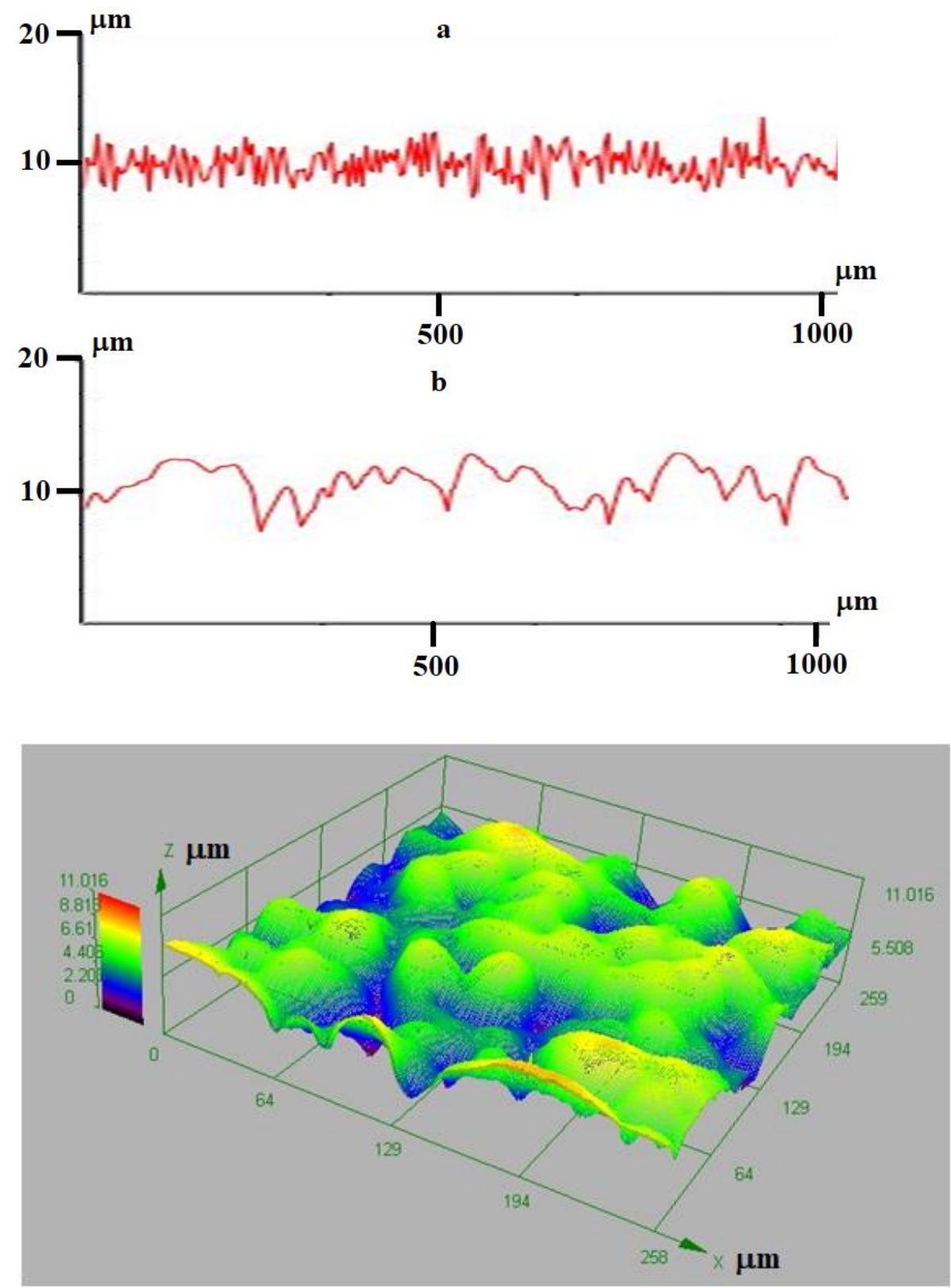

c

Figure 2. Surface morphology of copper coatings: a - microprofile of the coating formed in background electrolyte $1 ; \mathrm{b}$ - microprofile in the presence of the additive in electrolyte $2 ; \mathrm{c}-$ microrelief in the presence of additives. Electrodeposition was carried out at direct current on immovable samples. Fragments of profile diagrams $1 \mathrm{~mm}$ long are shown $(\mathrm{a}, \mathrm{b})$. The microrelief (c) was obtained from a micrograph $(\times 1000)$.

The formation of three-dimensional micro relief waves may be due to the appearance of so-called "secondary flows" in the course of electrodeposition, which arise under natural convection conditions due to a gradient of electrolyte density near the cathode and release of Joule heat during the electrolysis. 
Table 3. Distribution of the electrochemical copper layer on the surface and in the holes.

Sample No.

Roughness amplitude $R_{\mathrm{z}}^{*}, \mu \mathrm{m}$

\begin{tabular}{cc}
\hline Outer surface & At the hole half-depth \\
\hline 9 & 5 \\
17 & 17 \\
15 & 4 \\
5 & 5 \\
11 & 8 \\
12 & 7 \\
15 & 3 \\
5 & 4 \\
\hline
\end{tabular}
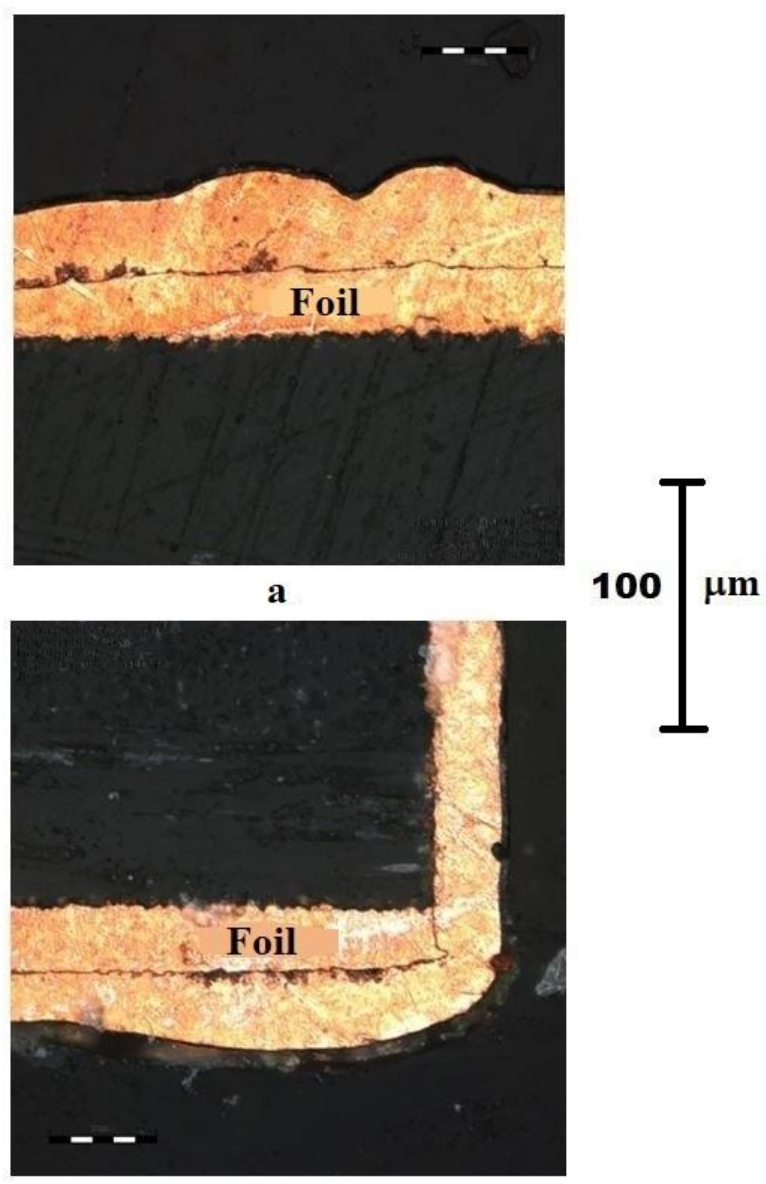

b

Figure 3. Micrographs $(\times 1000)$ of copper coatings obtained under direct current from electrolyte 2 containing a complex of additives: $a-$ on a fixed sample; $b$ - with rocking. 
According to [18], the effect of secondary flows on the formation of crystalline micro waviness (three-dimensional microwaves) is detected if differences in the local intensity of mass supply cause changes in the deposition kinetics. In particular, at a constant intensity of secondary fluxes, the micro waviness of deposits increases with an increase in the leveling ability of the electrolyte. In this case, in places where the supply of the additive is faster, the rate of copper deposition will decrease due to the inhibiting effect of the additive, while in the places with slower supply, it will increase.

The waviness of the outer surface relief, which is pronounced under natural convection conditions of copper electrodeposition in the presence of the complex of additives, persists to a noticeable extent even under forced convection conditions when the cathode rod rocks. The width of the wavy irregularities is $\sim 70-150 \mu \mathrm{m}$, the height is $\sim 5-15 \mu \mathrm{m}$, but their number decreases in the forced convection mode. Figure $3 \mathrm{~b}$ shows a wavy defect of the outer surface with a height of up to $\sim 20 \mu \mathrm{m}$. Its length is up to $\sim 150 \mu \mathrm{m}$ from the hole mouth, which in principle can worsen the uniformity of the copper layer in the contact areas [22]. In the presence of the additive, the height of narrow irregularities (up to $\sim 10 \mu \mathrm{m}$ ) does not exceed $\sim 1 \mu \mathrm{m}$. Apparently, the observed smoothing of submicron irregularities and the formation of a gentle wavy micro relief may be associated with the adsorption and inhibitory effect of additives in the complex formulation used in the copper electrodeposition process. It should be noted that the appearance of waviness in the micro relief during deposition in the presence of additives does not prevent brightening, which does not contradict the literature data [19]. As it was noted [19], not only surfaces with submicron irregularities but also surfaces with protrusions and depressions whose the linear dimensions range from several to hundreds micrometers can have a mirror gloss.

In the case of copper electrodeposition from a solution without additives in reverse mode, the micro relief has almost no waviness, but a dendritic surface with significant crystalline roughness is formed (Figure $4 \mathrm{c}$ ). In this case, the maximum irregularity height determined from the micrographs is up to $\sim 17 \mu \mathrm{m}$ (Table 3, sample 2) and the nature of the irregularities formed varies greatly. The formation of dendrites is observed not only in the middle of holes where it can be due to diffusion limitations for copper in the absence of mixing, but also everywhere on the outside of a sample. This effect can be due to the formation of $\mathrm{Cu}^{+}$ions during an anodic pulse followed by their reduction at limiting current [23]. The developed crystalline roughness of the external side of the sample is retained if the cathode rod is rocked: the maximum roughness height is also $\sim 12 \mu \mathrm{m}$ (Figure $5 \mathrm{~b}$, Table 3 , sample 6).

At the same time, upon electrodeposition from the electrolyte with the additives in the reverse mode, the wavy micro relief is not observed in direct current mode. The dendritic structure of the coating, which is pronounced in the case of current reversal in the absence of additives, also disappears. Thus, the width and height of irregularities both on the outside of the sample and in the middle of holes decrease significantly: the height of small irregularities up to $\sim 10 \mu \mathrm{m}$ wide is about $\sim 2-3 \mu \mathrm{m}$ (Figures $3-5$ ). The change in the morphology of the copper deposit obtained from the electrolyte with the additives observed 
upon current reversal makes it possible to state that coatings that are relatively uniform in thickness and have small surface roughness are formed.
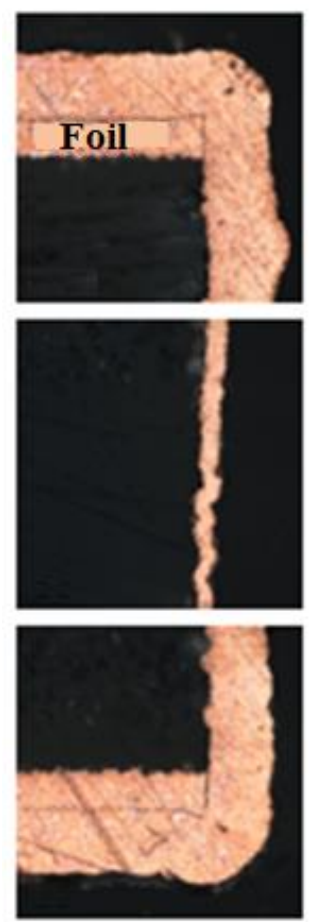

a
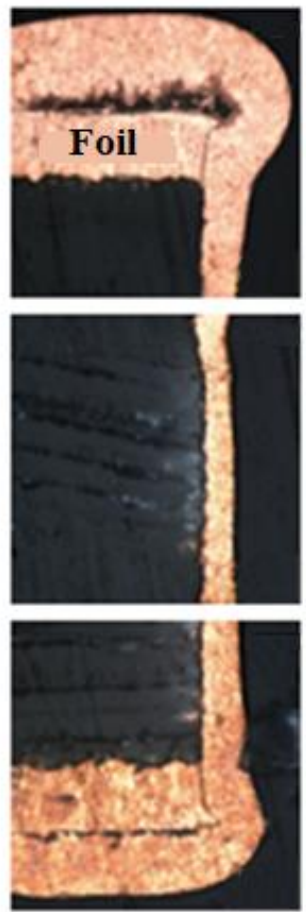

b
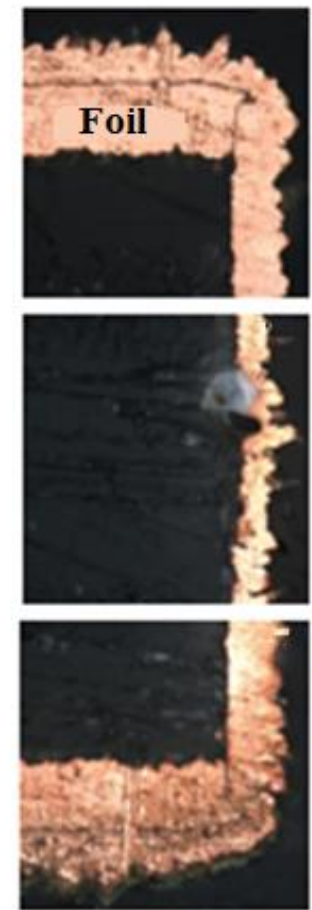

c
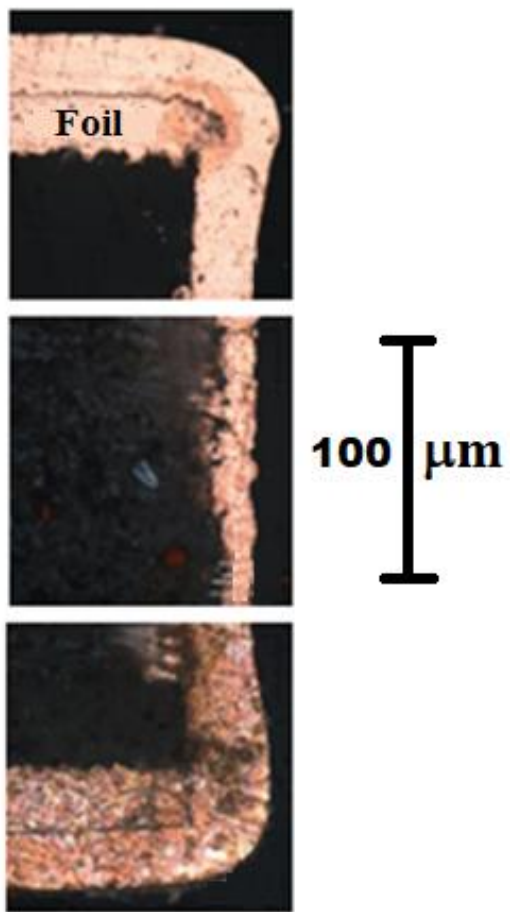

d

Figure 4. Micrographs $(\times 2000)$ of copper coatings in the through holes $0.2 \mathrm{~mm}$ in diameter in stationary samples: a, c - obtained from background electrolyte $1 ; \mathrm{b}, \mathrm{d}-$ from electrolyte 2 in the presence of the additive. Electrodeposition was carried out at constant current $(a, b)$ and with current reversal (c, d).

\section{Conclusion}

The simultaneous use of stirring and a certain reverse mode makes it possible to noticeably improve the distribution of the metal inside and on the surface of the item, both in the presence of modern additives inhibiting the copper deposition from sulfuric acid electrolytes and without them. If the electrolyte contains additives, a shallow wavy micro relief is formed without current reversal. If copper is electrodeposited from the solution without additives, the micro relief has almost no waviness in reverse mode, but a dendritic surface is formed. Only if all the three factors, i.e., current reversal, stirring, and additives, are in effect, uniformity of copper distribution on the surface of samples and deep in the holes is achieved, and coatings that are uniform in thickness and structure are obtained. 

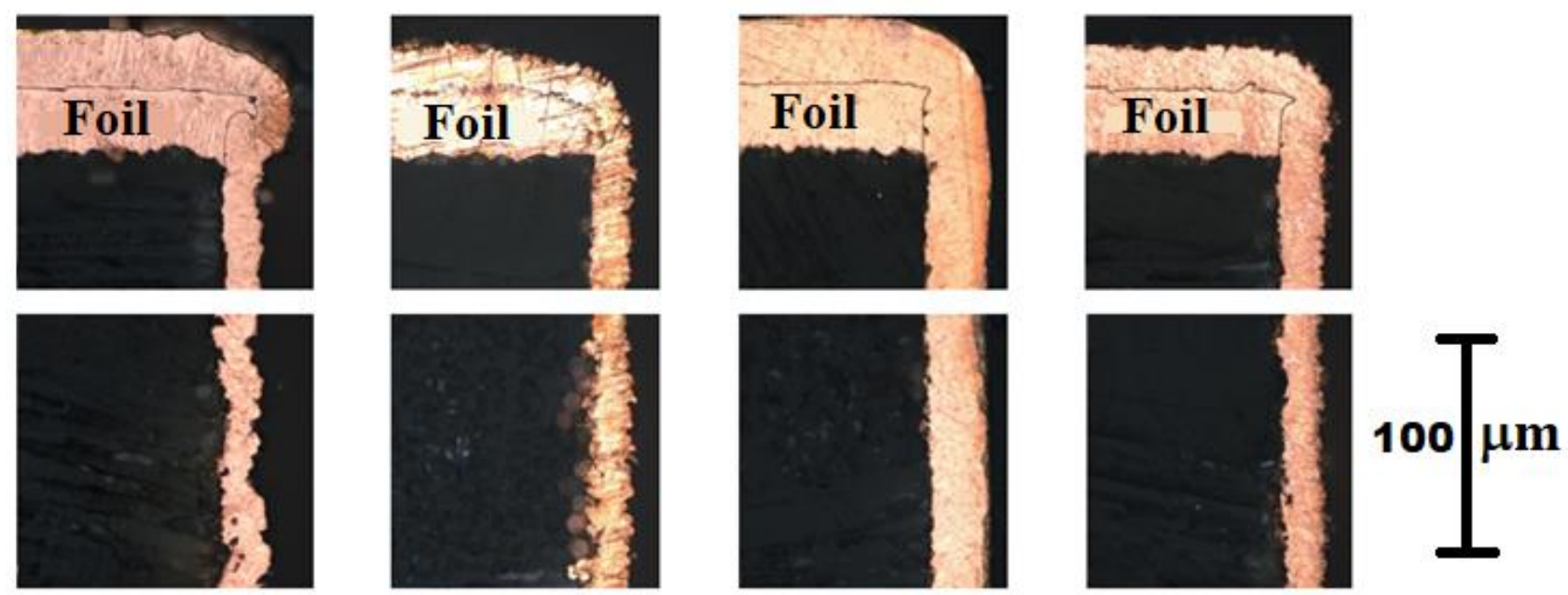

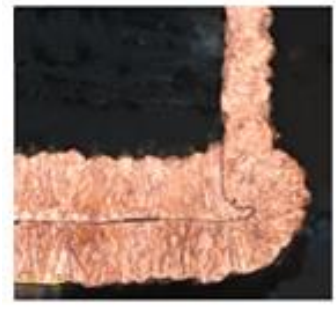

a

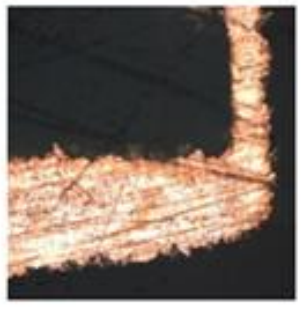

b

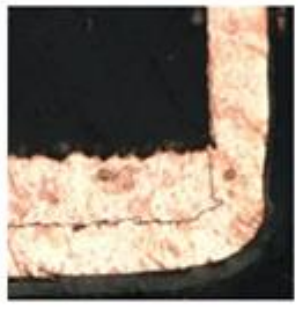

c

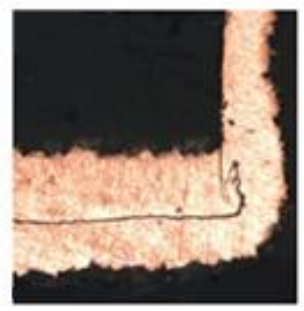

d

Figure 5. Micrographs of copper coatings in holes with a diameter of $0.4 \mathrm{~mm}(\times 2000)$ : a, c obtained from electrolyte $1 ; \mathrm{c}, \mathrm{d}$ - obtained from electrolyte 2 in the presence of the additive. The electrodeposition was carried out with direct current $(a, c)$ and with current reversal (c, d). The samples were obtained with rocking.

\section{References}

1. Yu.D. Gamburg, Gal'vanicheskie pokrytiya. Spravochnik po primeneniyu (Galvanic coatings. Application guide), Moscow, Tekhnosfera, 2006, 216 (in Russian).

2. N.T. Kudryavtsev, Elektroliticheskie pokrytiya metallami (Electrolytic metal coatings), Moscow, Khimiya, 1979, 352 (in Russian).

3. A. Medvedev and P. Semenov, Impul'snaya metallizatsiya pechatnykh plat, (Pulse metallization of printed boards), Tekhnologii $v$ elektronnoi promyshlennosti (Technologies in electronic industry), 2005, no. 4, 22-24 (in Russian).

4. S.S. Kruglikov, N.V. Titova, N.E. Nekrasova and A.F. Gubin, Rol' faktorov makro- i mikroraspredeleniya $\mathrm{v}$ protsessakh formirovaniya sloev metallov i splavov $\mathrm{v}$ proizvodstve pechatnykh plat i drugikh komponentov elektronnykh ustroistv (Role of micro and macro distribution factors in the formation of metal and alloy layers in the production of printed boards and other components of electronic devices), Teoreticheskie osnovy khimicheskoi tekhnologii (Theoretical bases of chemical technology), 2018, 52, no. 6, 663-675 (in Russian). doi: 10.1134/S0040357118060076 
5. A.M. Pesco and H.Y. Cheh, The current distribution within plated through-holes I. The effect of electrolyte flow restriction during DC electrolysis, J. Electrochem. Soc., 1989, 136, no. 2, 399-407.

6. M.R. Kalantary, D.R. Gabe and M.R. Goodenough, Unipolar and bipolar pulsed current electrodeposition for PCB production, J. Appl. Electrochem., 1993, 23, 231-240.

7. T.C. Chen, Y.L. Tsai, C.F. Hsu, W.P. Dow and Y. Hashimoto, Effects of brighteners in a copper plating bath on throwing power and thermal reliability of plated through holes, Electrochim. Acta, 2016, 212, 572-582. doi: 10.1016/j.electacta.2016.07.007

8. B. Tadesse, M. Horne and J. Addai-Mensah, The effect of thiourea, L(-) cysteine and glycine additives on the mechanisms and kinetics of copper electrodeposition, J. Appl. Electrochem., 2013, 43, 1185-1195. doi: 10.1007/s10800-013-0596-4

9. C. Wang, J. Zhang, B. Yang and M. An, Through-hole copper electroplating using nitrotetrazolium blue chloride as a leveler, J. Electrochem. Soc., 2013, 160, no. 3, 8588. doi: $10.1149 / 2.035303$ jes

10. Z.X. Wang, S. Wang, Z. Yang and Z.L. Wang, Influence of additives and pulse parameters on uniformity of through-hole copper plating, Trans. Inst. Met. Finish., 2010, 88, no. 5, 272-276. doi: 10.1179/002029610X12791981507884

11. A.A. Kosarev, A.A. Kalinkina, T.A. Vagramyan, A.N. Serov, N.E. Nekrasova and S.S. Kruglikov, Issledovanie vliyaniya parametrov impul'snogo reversivnogo toka i sostava rastvora na rasseivayushchuyu sposobnost' elektrolita medneniya (Study of the effect of pulsed reverse current parameters and solution composition on the dissipating capability of copper plating electrolyte), Gal'vanotekhnika i obrabotka poverkhnosti (Electroplating and surface treatment), 2017, 25, no. 2, 41-47 (in Russian).

12. M.I. Savel'ev, S.S. Kruglikov, M.M. Yarlykov and E.V. Braun, Elektroosazhdenie medi $\mathrm{v}$ glubokikh skvoznykh otverstiyakh malogo diametra (Copper electrodeposition in small-diameter deep through holes), Fizikokhimiya poverkhnosti $i$ zashchita materialov (Protection of Metals and Physical Chemistry of Surface), 1991, 27, no. 2, 298-300 (in Russian).

13. M.I. Savel'ev, S.S. Kruglikov, M.M. Yarlykov, E.V. Braun and A.N. Menglishev, O vyravnivanii elektroosazhdeniya medi v uzkom otverstii pri protoke elektrolita (Leveling of copper electrodeposotion in a narrow hole with electrolyte flow), Fizikokhimiya poverkhnosti $i$ zashchita materialov (Protection of Metals and Physical Chemistry of Surface), 1991, 27, no. 6, 1032-1034 (in Russian).

14. Myung Jun Kim, Taeho Lim, Kyung Ju Park, Soo-Kil Kim and Jae Jeong Kim, Pulsereverse electrodeposition of $\mathrm{Cu}$ for the fabrication of metal interconnection: Effects of anodic steps on the competitive adsorption of the additives used for superfilling, $J$. Electrochem. Soc., 2013, 160, no. 12, 3081-3087. doi: 10.1149/2.015312jes

15. IPC 4562 Metal Foil for Printed Wiring Applications.

16. A.M. Medvedev, Perspektivnyi material dlya izgotovleniya pechatnykh plat ustroistv SVCh-diapazona (A promising material for making printed circuits for UHF devices), Pechatnyi montazh (Printed circuit wiring), 2017, no. 5, 184-187. 
17. Jing Xiang, Shouxu Wang and Ling Li, Electrochemical factors of levelers on plating uniformity of trough-holes: simulation and experiments, J. Electrochem. Soc., 2018, 165, no. 9, 359-365. doi: $\underline{10.1149 / 2.0331809 \text { jes }}$

18. S.S. Kruglikov and N.Ya. Kovarskii, Vyravnivanie mikronerovnostei pri elektroosazhdenii metallov (Leveling of microroughness in electrodeposition of metals), Itogi nauki i tekhniki, ser. Elektrokhimiya (Itogi Nauki i Tekh., Ser.: Elektrokhim. (Advances in Science and Technology, Ser.: Electrochemistry), Moscow, VINITI, 1975, 10, 106-189 (in Russian).

19. Yu.Yu. Matulis, Blestyashchie elektroliticheskie pokrytiya (Glossy electrolytic coatings), Vilnius, Mintis, 1969, 612 (in Russian).

20. Yu.D. Gamburg, Elektrokhimicheskaya kristallizatsiya metallov $i$ splavov (Electrochemical crystallization of metals and alloys), Moscow, Yanus-K, 1997, 384 (in Russian).

21. GOST 20406-75, Platy pechatnye. Terminy i opredeleniya (Printed boards. Terms and definitions) (in Russian).

22. A. Akulin, Varianty ispolneniya pechatnykh plat s glukhimi i skrytymi otverstiyami (Variants of making printed boards with sealed and through holes), Tekhnologii $v$ elektronnoi promyshlennosti (Technologies in electronic industry), 2007, no. 3, 31-34 (in Russian).

23. S.S. Kruglikov, T.E. Yurchuk and A.E. Fedorova, Rol' ionov promezhutochnoi valentnosti $\mathrm{v}$ katodnom raspredelenii medi $\mathrm{v}$ sernokislom elektrolite (Role of intermediate valency ions in cathodic distribution of copper in sulfuric acid electrolyte), Elektrokhimiya, 1993, 29, 1020-1023 (in Russian). 